\title{
RESILIENCE SYSTEM OF COMPLEX AGROFORESTRY WITH ALBIZIA AS THE MAIN STAND IN WEST JAVA
}

\author{
(Sistem Resiliensi Agroforestri Kompleks dengan Sengon Sebagai Tegakan Utama di Jawa \\ Barat)
}

\author{
Marcellinus M.B. Utomo \\ Balai Penelitian dan Pengembangan Teknologi Agroforestry \\ Jalan Raya Ciamis-Banjar km.4.Ciamis, Jawa Barat 46271 \\ e-mail: marcell.utomo@gmail.com
}

Diterima 26 Mei 2020; direvisi 27 Juli 2020; disetujui: 28 Juli 2020

\begin{abstract}
ABSTRAK
Dinamika dalam pengelolaan hutan secara umum termasuk di dalamnya agroforestry selalu terkait dengan perubahan ekologi dan sosial. Lebih dari 30 tahun, pola hutan rakyat yang umum dikembangkan oleh masyarakat terutama di Jawa Barat memakai pola agroforestry kompleks. Saat ini, salah satu tanaman penghasil kayu primadona petani adalah sengon (Falcataria moluccana). Namun demikian, dalam beberapa tahun terakhir, serangan karat tumor menjadi masalah serius bagi para petani. Dengan meminjam pendekatan sistem resiliensi, tulisan ini memaparkan bagaimana sistem resiliensi agroforestry kompleks dengan sengon sebagai tegakan utama ini berjalan dalam kaitannya dalam menyediakan sumber penghidupan yang berkesinambunagn sejauh ini bagi para petani agroforestri kompleks dengan segala dinamikanya terutama dalam 10-20 tahun terakhir terutama dengan adanya serangan karat tumor. Dengan memilih lokasi penelitian di desa Kalijaya, Kabupaten Ciamis, Provinsi Jawa Barat, tulisan ini bertujuan untuk memahami bagaimana sistem resiliensi di lanskap tersebut berjalan. Pemahaman ini menjadi dasar untuk memberikan rekomendasi pada lanskap Desa Kalijaya secara khusus dan hutan rakyat yang setipe di Jawa Barat pada umumnya agar lahan agroforestri tetap mampu atau bahkan lebih meningkatkan penghidupan petani dengan mengantisipasi berbagai ancaman yang mungkin terjadi di kemudian hari dengan mempertimbangkan peran yang dapat dilakukan oleh pihak-pihak yang terkait dengan agroforestri.
\end{abstract}

Kata kunci: sistem resiliensi, sengon, agroforestri, kompleks, penghidupan, karat tumor

\begin{abstract}
The dynamics in forest management in general as well as in agroforestry are always associated with ecological and social changes. For more than 30 years, the common pattern of community forests especially in West Java applies a complex agroforestry pattern. Currently, one of the most popular trees is albizia (Falcataria moluccana). However, in the past years, gall rust attack becomes a serious problem for the farmers. By borrowing a resilience system approach, this paper describes how a complex agroforestry resilience system with albizia as the primary stand is working in relation to providing sustainable livelihoods so far for the complex agroforestry farmers with all the dynamics especially in the last 10-20 years particularly related to gall rust attack. By selecting a research site in the village of Kalijaya, Ciamis District, West Java Province, this paper aims to understand how the resilience system works in this landscape. The understanding will be a baseline propose some recommendations for the landscape of the villages of Kalijaya specifically and the same type community forests in West Java in general in order to make agroforestry landscapes remain capable or even improving the farmer livelihood by anticipating various threats that may occur in the future by taking into consideration the role that can be undertaken by agroforestry-related parties.
\end{abstract}

Keywords: resilience system, albizia, agroforestry, complex, livelihood, gall rust

\section{INTRODUCTION}

One province among 34 provinces in Indonesia that has a strong tradition in 
agroforestry is West Java. West Java province consists of 18 districts and the district that produces the second largest farmed wood is Ciamis (Statistic-Indonesia-of-West-Java, 2015). Ciamis people have been familiar with agroforestry, combining forestry tree species and agricultural plant species in the same place, where the main target of forestry plant is producing wood as a long-term investment and for the agricultural plant as a short-term investment. People have recognised this farming method a long time ago, and call it as "tumpang sari" and they deem stands as their investment (Hamdani, Darusman, \& Tiryana, 2015).

A common form of agroforestry in West Java is complex agroforestry. Complex agroforestry means farmers utilise all sides of the farm for planting numerous plant species. Complex agroforestry consists of three types of commodities; wood-producer, fruitproducer, and medicine-producer trees. These are utilised for both domestic consumption and commercial use. Farmers usually do not employ systematic planning where they plant, without the rigid rule in terms of plant spacing between species. Thus, the form of landscape usually does not look like a modern plantation, but mini natural-liked forests.

Scientists have been going to formulate a pattern to determine the best agroforestry pattern in terms of plant spacing and the number of each species limitation to promote better growths. However, its implementations could trigger some drawbacks. For an example, when a pest or disease attacks the main tree species, thus farmers cannot reap the yield. As a result, farmers will lose the opportunity for getting income. On the other hand, when farmers keep planting many species, they still have opportunities to get incomes from other commodities when a disease devastates a species. A complex agroforestry system also has a time function, because when farmers wait wood producer trees to grow, they can utilise other plant species that produce nonwood products, which sometimes they relatively grow more rapidly and generates commercial products periodically. Those seem to be the reasons behind people choosing complex agroforestry system.

A severe disturbance occurred in private forests with albizia as the main stand. At least in the last 15 years, gall rust attack by Uromycladium falcatarianum sp. nov (Doungsa-ard et al., 2015) in albizia is the main problem in farm forests in Indonesia and this outbreak was widespread throughout the country (Syakirin, 2014) . This disease started attacking Albizia stands in Java since 2005 (Diputra, Rahayu, \& Baskorowati, 2015). As Albizia stands dominantly developed in private forests, this attack devastated the economy of small-scale forest farmers. However, interestingly, this disturbance does not totally change the farming tradition of farmers to manage albizia as the main stands in private forests in West Java. The ways of people and fast-growing-wood business actors adapt to disease attack show that resilience system in West Java private forests exists. So far, global academic discussions have not yet discussed how the community itself resilient to gall rust disturbance in their private forest. Discussion of this gall rust phenomenon globally is limited. The global context mostly focuses on how the forests adapt to global changes, like fires (Hart et al., 2019), land-use changes (Ayala-Orozco et al., 2018), drought (Gazol, Camarero, Sangüesa-Barreda, \& Vicente-Serrano, 2018; Gazol, Camarero, Vicente-Serrano, et al., 2018), climate changes (Gnonlonfoun, Assogbadjo, Gnanglè, \& Kakaï, 2019; Messier et al., 2019), and beetle outbreaks (Campbell \& Antos, 2019). This paper aims to firstly discuss and evaluate why this preference is resilient using the resilience assessment approach in order to understand the dynamics of complex agroforestry in West Java in the last 15 years. Secondly, this paper aims to enrich the discussion of the socio-ecological resilience system in agroforestry in the Indonesian context. By this understanding, it could also 
be useful to deal with any disturbance may occur in private forests in the future.

\section{RESEARCH METHOD}

\section{A. Research Site and Procedure}

The location assessed in this research is a complex agroforestry landscape in Kalijaya village. This village is a part of Banjarsari Sub-district, Ciamis District, West Java Province, Indonesia. The landscape of this location represents on how private forests work in West Java.

This research applied the survey method by implementing field checking and data gathering from interviews with farmers and key respondents. The research took place in January 2016. To crosscheck the validity of the data, the data was collected until saturation is reached. The main information consist of the main stands they have, problems occur in growing albizia and how actors run their agroforestry business especially related to albizia trade.

\section{B. Data Analysis}

The qualitative analysis is performed in this paper by using a resilience system approach (Walker \& Salt, 2012). This approach could help forestry researchers to build an understanding on how a landscape system works and its connection from past to present condition and make future predictions possible be presented and thus some recommendations could be proposed. This approach performs an assessment that overarches three main stages including system dynamics, cross-scale interactions, and acting on resilience.

\section{RESULT AND DISCUSSION}

\section{A. System Dynamics}

In system dynamics, there are three aspects discussed, i.e. the adaptive cycle of Kalijaya landscape using a model developed by (Holling \& Gunderson, 2002), multiple states in the system, and the thresholds and transitions. The adaptive cycle in the focal scale consists of four phases (see Figure 1); rapid growth, conservation, release, and reorganisation. In rapid growth phase, the fast-growing wood species became popular amid the farmers and it replaced the prior hardwood species. At that time, all farmers planted albizia. Albizia became the first choice of farmers to plant at their arable land, even at their back yards. We consider this phase is the conservation phase, in which farmers perceive that if they want to earn money in the fastest way, they should cultivate albizia. However, a disaster came when gall rust spread and became an epidemic in 2008. This situation seems like a catastrophe for agroforestry in Indonesia. Most of the young stand was decimated. This is the releasing phase, where this disturbance was unpredicted, although the first appearance of this disease firstly found in 1996 in Moluccas (Rahayu, 2010). Given that the resilience system comes with a cost, it is also true in this system. Farmers have spent a lot of money to cultivate albizia and they have to adapt to this failure. They chose to plant another fast-growing wood species, where many farmers started planting jabon/kadam tree (Anthocephalus cadamba). We consider this is a reorganisation phase. 


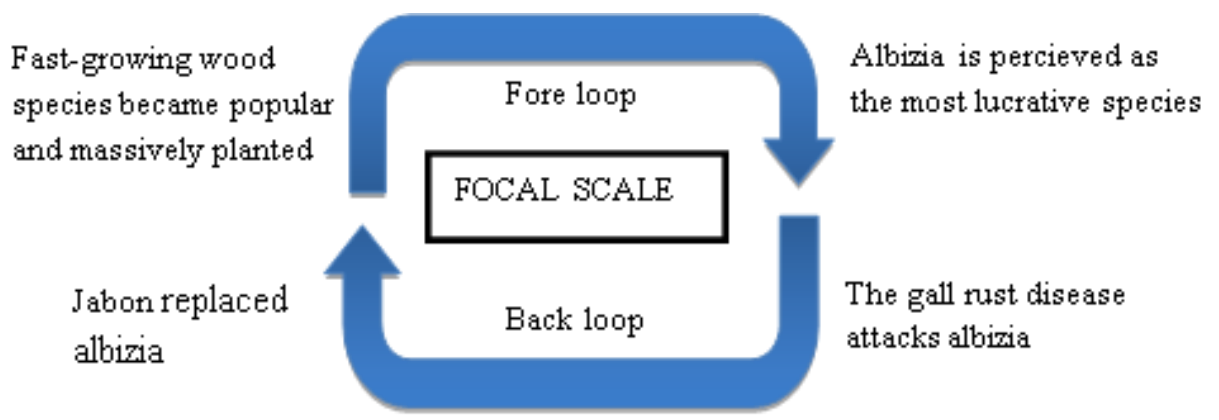

Figure 1. Adaptive cycle of Kalijaya landscape system

Gambar 1. Rantai adaptif sistem lanskap Kalijaya

The stable state does not necessarily mean that it is always in the same form. Although the form is always complex agroforestry and able to support farmers' economies by providing woods, fruits, and cardamom, the states have changed for at least in 4 states. Those states are related to vegetation composition. The figure below illustrates the past and current state as well as the possible or future states. The transition between states requires threshold(s) that have been crossed, either social or ecological thresholds. The first state is when the composition consists of hardwood, fruits, and cardamom (state A). The thresholds that initiate state shifting are shown in the table below.

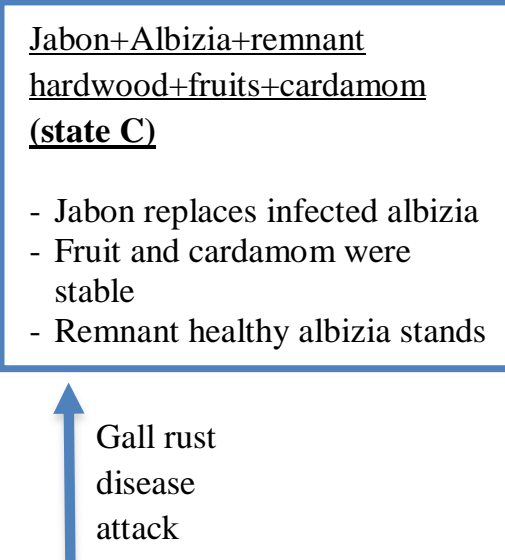

Albazia+remnant hardwood+fruits+cardamom composition (state B)

- Albizia became popular, replace almost all hardwood stands

- Left small percentage of hardwood stands

- Fruit and cardamom stands were stable

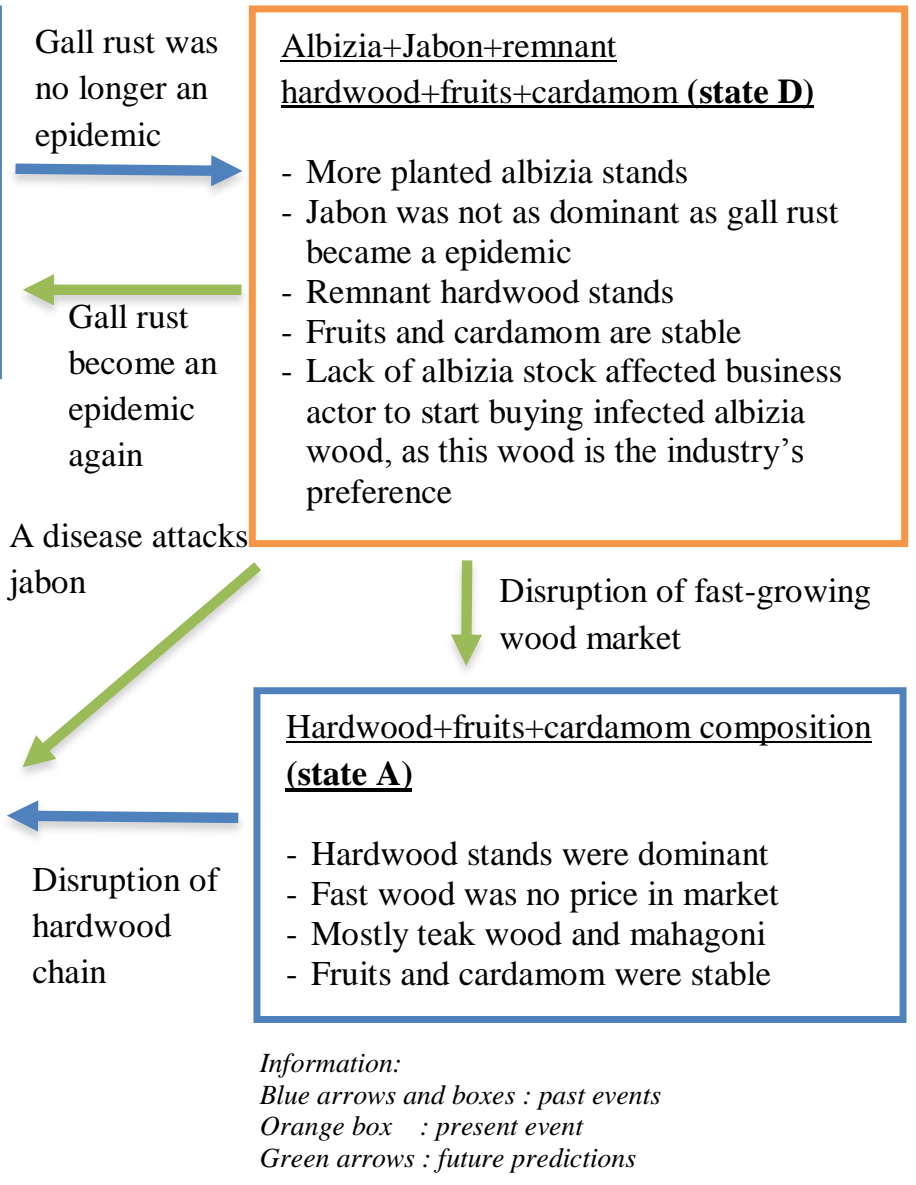

Albizia+Jabon+remnant

- More planted albizia stands

- Jabon was not as dominant as gall rust

- Fruits and cardamom are stable Lack of albizia stock affected busines actor to start buying infected albizia wood, as this wood is the industry's preference

$$
\begin{aligned}
& \text { A disease attacks } \\
& \begin{array}{ll}
\text { jabon } & \begin{array}{l}
\text { Disruption of fast-growing } \\
\text { wood market }
\end{array} \\
& \frac{\text { Hardwood+fruits+cardamom composition }}{\text { (state A) }} \\
\text { Disruption of } & \text { - Hardwood stands were dominant } \\
\text { hardwood } & \text { - Fast wood was no price in market } \\
\text { chain } & \text { - Mostly teak wood and mahagoni } \\
& \text { - Fruits and cardamom were stable } \\
& \begin{array}{l}
\text { Information: } \\
\text { Blue arrows and boxes : past events } \\
\text { Orange box : present event } \\
\text { Green arrows : future predictions }
\end{array}
\end{array}
\end{aligned}
$$

Figure 2. Summary of multiple states in Kalijaya landscape Gambar 2. Ringkasan tahapan kondisi lanskap Kalijaya 
Table 1. The focal system disturbances and its attributes

Tabel 1. Gangguan pada focal system and atributnya

\begin{tabular}{|c|c|c|c|c|}
\hline \multirow{2}{*}{$\begin{array}{l}\text { Transition } \\
\text { between } \\
\text { states } \\
\text { (transisi } \\
\text { antar } \\
\text { tahapan) } \\
\text { Past } \\
\text { (lampau) }\end{array}$} & \multirow{2}{*}{$\begin{array}{c}\text { Transition } \\
\text { character } \\
\text { (karakter } \\
\text { transisi) }\end{array}$} & \multicolumn{2}{|c|}{$\begin{array}{c}\text { Crossed thresholds } \\
\text { (ambang batas yang dilewati) }\end{array}$} & \multirow{2}{*}{$\begin{array}{c}\text { Any relationship between } \\
\text { thresholds } \\
\text { (ada/tidaknya hubungan antar } \\
\text { ambang batas) }\end{array}$} \\
\hline & & $\begin{array}{l}\text { Social } \\
\text { (sosial) }\end{array}$ & $\begin{array}{c}\text { Ecological } \\
(\text { ekologis })\end{array}$ & \\
\hline A-B & $\begin{array}{l}\text { Sudden } \\
(\text { tiba-tiba) }\end{array}$ & $\begin{array}{l}\text { Availability of hardwood } \\
\text { and capability of wood } \\
\text { industry to pay hardwood/ } \\
\text { marketing flexibility of } \\
\text { hardwoods (ketersediaan } \\
\text { kayu keras dan } \\
\text { kemampuan industri untuk } \\
\text { membeli kayu } \\
\text { keras/fleksibilitas pasar } \\
\text { kayu keras) }\end{array}$ & $\begin{array}{l}\text { Land capability to } \\
\text { support certain number } \\
\text { of plant (kemampuan } \\
\text { tanah untuk mendukung } \\
\text { tanaman dalam jumlah } \\
\text { tertentu) }\end{array}$ & No (tidak) \\
\hline $\mathrm{B}-\mathrm{C}$ & $\begin{array}{l}\text { Sudden } \\
\text { (tiba-tiba) }\end{array}$ & $\begin{array}{l}\text { Farmers' income from } \\
\text { albizia wood (pendapatan } \\
\text { petani dari sengon) }\end{array}$ & $\begin{array}{l}\text { Immunity of Albizia } \\
\text { against gall rust } \\
\text { (imunitas sengon } \\
\text { terhadap karat tumor) }\end{array}$ & $\begin{array}{l}\text { Yes, many perished albizia } \\
\text { stands affect the farmers' } \\
\text { economy (Ya, banyak sengon } \\
\text { yang mati memengaruhi } \\
\text { ekonomi petani) }\end{array}$ \\
\hline C-D & $\begin{array}{c}\text { Gradual } \\
\text { (bertahap) }\end{array}$ & - & $\begin{array}{l}\text { Ability of gall rust to } \\
\text { infect (kemampuan karat } \\
\text { tumor untuk menginfeksi) }\end{array}$ & No (tidak) \\
\hline \multicolumn{5}{|l|}{$\begin{array}{l}\text { Future } \\
\text { (masa } \\
\text { depan) }\end{array}$} \\
\hline D-A & $\begin{array}{c}\text { Gradual } \\
\text { (bertahap) }\end{array}$ & $\begin{array}{l}\text { The feasibility of fast } \\
\text { wood (kelayakan } \\
\text { pengusahaan kayu cepat } \\
\text { tumbuh) }\end{array}$ & $\begin{array}{l}\text { Degraded land (tanah } \\
\text { terdegradasi) }\end{array}$ & $\begin{array}{l}\text { Yes, when the land loss its } \\
\text { capability to support plantation } \\
\text { (Ya, saat tanah kehilangan } \\
\text { kemampuan untuk mendukung } \\
\text { tanaman) }\end{array}$ \\
\hline D-B & $\begin{array}{l}\text { Sudden } \\
\text { (tiba-tiba) }\end{array}$ & $\begin{array}{l}\text { Feasibility/ Economic } \\
\text { balance of jabon } \\
\text { (kelayakan pengusahaan } \\
\text { kayu jabon) }\end{array}$ & $\begin{array}{l}\text { Immunity of jabon } \\
\text { (imunitas jabon) }\end{array}$ & $\begin{array}{l}\text { Yes, when jabon stands fail to } \\
\text { provide wood, it will be } \\
\text { detrimental for farmers ( } Y a \text {, } \\
\text { saat tegakan jabon gagal } \\
\text { memberikan hasil bagi petani) }\end{array}$ \\
\hline $\mathrm{D}-\mathrm{C}$ & $\begin{array}{l}\text { Sudden } \\
\text { (tiba-tiba) }\end{array}$ & $\begin{array}{l}\text { Feasibility/ Economic } \\
\text { balance of albizia wood } \\
\text { (kelayakan pengusahaan } \\
\text { kayu sengon) }\end{array}$ & $\begin{array}{l}\text { Immunity of Albizia } \\
\text { against gall rust } \\
\text { (imunitas sengon } \\
\text { terhadap karat tumor) }\end{array}$ & $\begin{array}{l}\text { Yes, when gall rust becomes } \\
\text { an epidemic again, it will } \\
\text { devastate albizia stands ( } \mathrm{Ya} \text {, } \\
\text { saat karat tumor menjadi } \\
\text { pandemic kembali dan } \\
\text { merusak tegakan sengon) }\end{array}$ \\
\hline
\end{tabular}

\section{B. Cross-Scale Interactions}

In the resilience system, small-scale and large-scale adaptive cycles influence the focal scale (Resilience-Alliance, 2010) (summarised in Figure 3). In Kalijaya landscape, the small scale is started by the developing trend of hardwood market and it became the main wood commodity from agroforestry at that time (around 20 years ago). However, the market changed as it was triggered by political chaos in 1997-1998 in which forests especially fancy wood plantation forests were plundered (Gunawan, 
Prasetyo, Mardiastuti, \& Kartono, 2012). Thus, the market of fast wood opened. Given that the market of fast wood was more lucrative than hardwood, it was a sign of releasing stage in this small scale. Since then, fast-growing wood species became the farmers' first choice for wood species in agroforests. This releasing stage is a "revolt". In the focal scale, it becomes the conservation stage with Albizia is perceived as the most lucrative wood species with the high flexibility for selling and its rapid growth.

In the focal scale the rapid growth stage was the fast-growing tree species became dominant in agro-forests. The sign of releasing process is when the gall rust attacks became an epidemic. In reorganisation stage, farmers responded to this situation by developing jabon as albizia's replacement. The jabon development is a "memory" from the large-scale adaptive cycle, as fast wood species has become farmers' preference. They perceive that fast wood is still more lucrative than hardwood species. Moreover in large scale, in the rapid growth stage, government supports were rising through their aid program and policy for agroforestry. Therefore, farmers persist to keep cultivating fast-growing wood species. For the releasing process, gall rust was no longer an epidemic and the wood business has transformed and accepted to buy infected albizia wood. That is why farmers start redeveloping albizia. Put simply, in this panarchy (cross-scale interactions cycle), the revolt is that market of fast wood is perceived more lucrative than hardwood market, and the memory is the benefits from fast wood species have created new tradition for farmers and influenced the farmers to keep prioritising fast-growing wood species rather than slow-growing hardwood species.

\section{Acting on Resilience (Recommendation)}

According to the resilience assessment processes above, we infer that the Kalijaya landscape is resilient in providing economic benefits for farmers. This landscape has been contributing to local farmers' incomes by providing woods, fruits, and cardamom. For the last two commodities, the markets are relatively stable and the disturbance has not come yet or we have not found any damaging disturbances for these commodities. The major change is in wood commodities where there was a shift from hardwood to fastgrowing wood commodities. It has been almost 20 years since the rising of fast wood species firstly emerged. Despite there is a detrimental disturbance from gall rust disease, the system adapts by introducing another fastgrowing wood species, like jabon. This trend seems unlikely to shift from fast-growing wood to hardwood in the near future as the development of technology has enabled wood companies to keep producing good quality processed wood products like veneer, core block, and blockboard. The second reason is the memory of farmers on how successful of fast-growing wood plantation mostly albizia to increase the farmer incomes, followed by its "livelihood function", as fast wood is more flexible than hardwood in terms of marketing. It is saleable even though the trees remain immature.

The government and business sectors have also adapted to the gall rust phenomenon. The government has increased its attention in the agroforestry sector, as it could be a motor for the rural economy. For business sector, the stakeholders have shifted their preference on wood stock, as now they want to buy infected albizia wood. However, this system still requires some improvements, particularly in increasing the economic values for the farmers. Therefore, we need to fix several points in this system.

We consider there are two management interventions in terms of supporting farmers' economy and preserving the conservation or biodiversity values of this landscape (Table 2). To keep this landscape resilient, we require targeting the main actor that is farmer. The farmers' prosperity should be the government priority. Actually, through this 
approach, several benefits can be derived, such as preserving farming culture, fostering farmers' incomes, and conserving biodiversity. It is important to address biodiversity as Java Island has been massively modified and this kind of landscape can foster the conservation program.

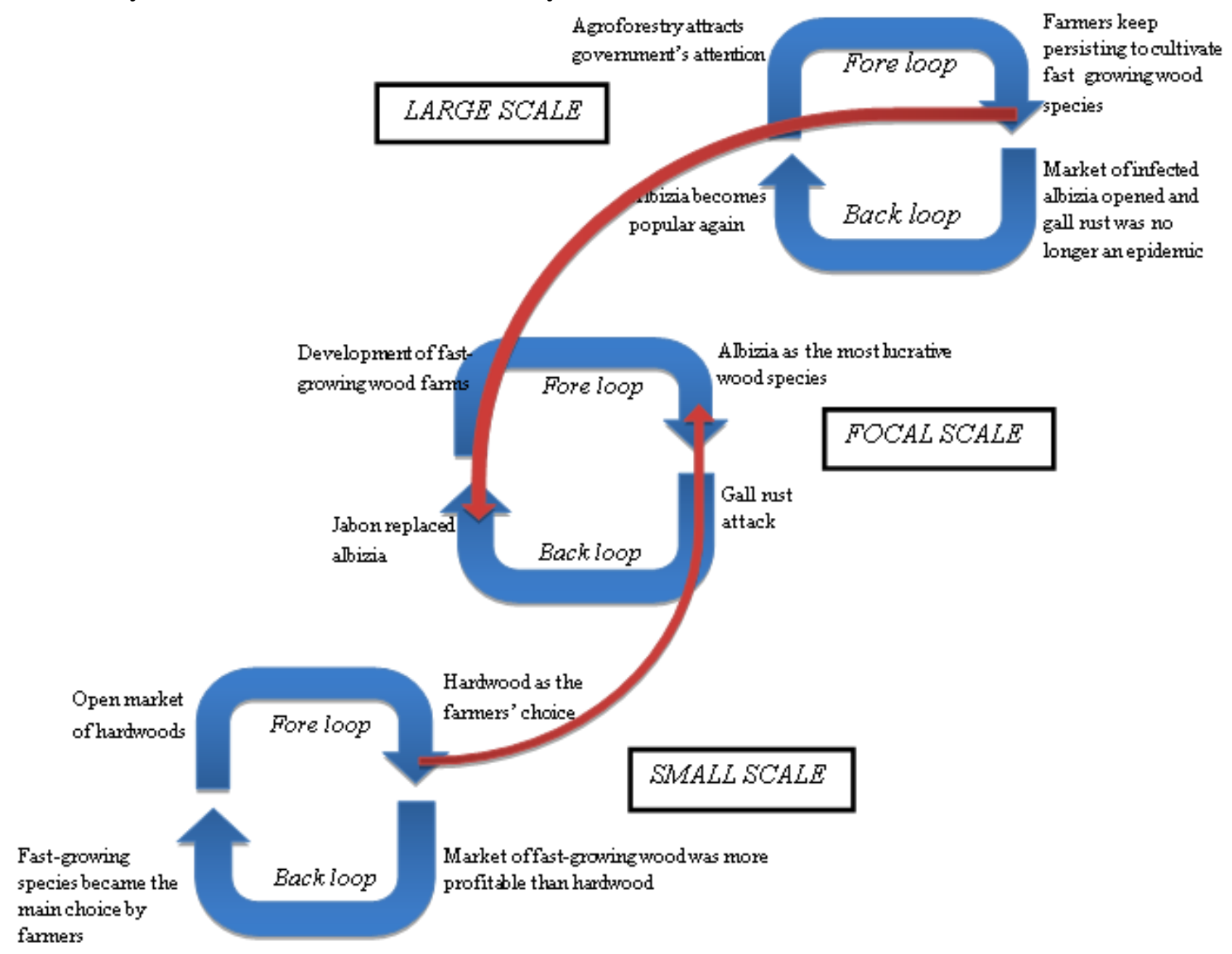

Figure 3. The panarchy of Kalijaya landscape system Gambar 3. Panarchy sistem lanskap Kalijaya 
Table 2. Management interventions

Tabel 2. Intervensi manajemen

Maintain farming culture and fostering farmers' income (memelihara budaya tanam dan membantu peningkatan pendapatan petani)

- Government should facilitate commodities' marketing by monitoring and if necessary intervening the market chains (pemerintah sebaiknya memfasilitasi pemasaran komoditas melalui monitoring dan bila perlu mengintervensi rantai pasar)

- Farmers should prepare regeneration by engaging local young generation in farming (petani sebaiknya menyiapkan generasi penerus pertanian)

- Initiating enrichment programs to diverse farming incomes, either by combining with livestock or beekeeping, in potential places (menginisiasi program pengayaan kegiatan usaha untuk menambah jenis pendapatan petani, dapat dilakukan dengan mengombinasikan dengan peternakan dan perlebahan)

- Government should guarantee that those commodities coined above are saleable, or at least government can open the new market, as sometimes marketing commodities is an issue for farmers (pemerintah sebaiknya menjamin komoditas tersebut diatas laku di pasaran)

- $\quad$ Providing subsidies for fertiliser (penyediaan subsidi pupuk)

Maintain biodiversity (memelihara keanekaragaman hayati)

- Banning any illegal hunting, especially bird hunting (melarang setiap perburuan liar, terutama perburuan burung)

- $\quad$ Providing extensions for the farmers about the important values of that landscape for biodiversity (menyediakan penyuluhan bagi petani tentang nilai pentingnya biodiversitas bagi lanskap)

- Providing incentives for farmers that involve on conservation programs (menyediakan insentif bagi petani yang terlibat dalam program konservasi)

In Indonesia context, in general, the farmer is perceived as not a prospective occupation as it does not provide enough incomes (Lumintang, 2013). Therefore, as a farmer is a main stakeholder in agricultural and forestry sectors, the farmers' livelihoods must be set as the government priority to ensure the agricultural sector keeps running and contributing to local and national development. In Indonesia where the number of population is high, and now is expected to reach 250 million inhabitants (StatisticsIndonesia-of-West-Java, 2014), the fourth most populous country in the world after China, India, The USA (US-Census-Bureau, 2015), the shifting from traditional to modern agriculture system can trigger several problems. It is noteworthy that the traditional model is able to create more employment, as it is labour intensive. However, when we persist to prevail in modern agriculture, in terms of individual, it will raise the incomes. In addition, modern agriculture also tends to diminish social culture like "gotong royong" or communal work, whereas it is a part of social capital. Accordingly, the challenge now is how to optimise land productivity, protect the farmers' markets, and get over the Indonesian farmer realm in order to attract more young generation for involving in the farm. On the table below, we propose several strategies for improvement in the complex agroforestry landscape syste

Table 3. Strategies for transformation

Tabel 3. Strategi transformasi

\begin{tabular}{lccc}
\multicolumn{1}{c}{ Strategies } & Actions & Barrier of change \\
\multicolumn{1}{c}{ Strategi } & Aksi & Halangan untuk perubahan \\
\hline Increasing land productivity & $\bullet$ Developing superior seeds, thus for $\bullet$ Limited research funding and \\
(Peningkatan produktivitas lahan) & wood species it will be more institutional culture that sometimes \\
& resistant to disease and better is slow to respond farmers/ grass \\
\hline
\end{tabular}




\begin{tabular}{|c|c|c|}
\hline $\begin{array}{l}\text { Strategies } \\
\text { Strategi }\end{array}$ & $\begin{array}{l}\text { Actions } \\
\text { Aksi }\end{array}$ & $\begin{array}{c}\text { Barrier of change } \\
\text { Halangan untuk perubahan }\end{array}$ \\
\hline & $\begin{array}{l}\text { growth, and for fruit species, it can } \\
\text { produce better fruit in terms of } \\
\text { quantity and quality, more resistance } \\
\text { to disease (pengembangan benih } \\
\text { unggul untuk spesies kayu yang } \\
\text { lebih tahan penyakit, dan untuk } \\
\text { spesies buah-buahan, dapat } \\
\text { menghasilkan kuantitas and kualitas } \\
\text { yang lebih baik dan tahan penyakit) } \\
\text { - Facilitating subsidised fertiliser } \\
\text { (fasilitasi pupuk bersubsidi) }\end{array}$ & $\begin{array}{l}\text { root interests (kurangnya dana } \\
\text { penelitian dan budaya institusi yang } \\
\text { lambat merspon kepentingan petani) }\end{array}$ \\
\hline $\begin{array}{l}\text { Increasing control, protecting, and } \\
\text { facilitating market } \\
\text { (Peningkatan control, perlindungan, } \\
\text { dan fasilitasi pasar) }\end{array}$ & $\begin{array}{l}\text { - Government intervention to control } \\
\text { the minimum price of commodity } \\
\text { (intervensi pemerintah dalam } \\
\text { mengontrol harga minimum dari } \\
\text { suatu komoditas) } \\
\text { - Accelerating village development, } \\
\text { including public facility and road } \\
\text { access (percepatan pembangunan } \\
\text { desa termasuk fasilitas umum dan } \\
\text { akses jalan }\end{array}$ & $\begin{array}{l}\text { - Related institutions seem have not } \\
\text { enough power to intervene wood } \\
\text { companies in controlling the price } \\
\text { (institusi terkait sepertinya tidak } \\
\text { memiliki kekuatan yang cukup untuk } \\
\text { mengontrol harga dari industry } \\
\text { kayu) } \\
\text { - Development programs tend to } \\
\text { target the urban area (program } \\
\text { pembangunan lebih menarget } \\
\text { daerah urban) }\end{array}$ \\
\hline $\begin{array}{l}\text { Anticipating the lack of young } \\
\text { generation involve in farming sector } \\
\text { (Antisipasi kurangnya generasi muda } \\
\text { yang terlibat dalam pertanian) }\end{array}$ & $\begin{array}{l}\text { - Continuing and strengthening rural } \\
\text { program of "bachelor students foster } \\
\text { the village" (melanjutkan dan } \\
\text { memperkuat program sarjana } \\
\text { membangun desa) }\end{array}$ & $\begin{array}{l}\text { - The lack of robust planning } \\
\text { (kurangnya perencanaan yang kuat) } \\
\text { - The uncertain perpetuity of the } \\
\text { policy that supports village } \\
\text { development (ketidakjelasan atas } \\
\text { keberlanjutan kebijakan yang } \\
\text { mendukung pembangunan desa) }\end{array}$ \\
\hline
\end{tabular}

\section{CONCLUSION RECOMMENDATION}

AND

\section{A. Conclusion}

Albizia remains the main wood stand in agroforestry lands, especially in West Java. This phenomenon does not totally change even though gall rust pandemic had attacked. This shows that albizia plantation is a reliance to this disturbance. The key of this resilience system is its adaptive cycle. How the people or parties can adapt to a new condition. It is concluded that albizia stands in West Java, represented by Kalijaya landscape, is resilience to gall rust pandemic and it remains the main wood stand in agroforestry lands.

\section{B. Recommendation}

The phenomenon of gall rust attack in other places in Indonesia is also worth to be documented, especially in areas where the social culture is different. This can enrich the discussion on how those people cope with this problem. By these discussions might end up with a wider knowledge of the resilience system of albizia on a broader scale.

\section{ACKNOWLEDGEMENT}

The author would like to thank Dr. David Freudenberger who has introduced the theory of resilience system. The author is also indebted to Australia Awards that makes this research possible.

\section{REFERENCES}


Ayala-Orozco, B., Gavito, M. E., Mora, F., Siddique, I., Balvanera, P., Jaramillo, V. J., . . . Martínez-Meyer, E. (2018). Resilience of soil properties to land-use change in a tropical dry forest ecosystem. Land Degradation \& Development, 29(2), 315-325. doi:10.1002/ldr.2686

Campbell, E. M., \& Antos, J. A. (2019). Resilience of southern Yukon boreal forests to spruce beetle outbreaks. Forest ecology and management, 433, 52-63. doi:10.1016/j.foreco.2018.10.037

Diputra, I. M. M. M. D., Rahayu, S., \& Baskorowati, L. (2015). Respons sengon (Falcataria moluccana (Miq.) Barneby \& JW Grimes) provenans Papua dan ras lahan Jawa terhadap penyakit karat tumor. (Master), Universitas Gadjah Mada,

Doungsa-ard, C., McTaggart, A. R., Geering, A. D., Dalisay, T. U., Ray, J., \& Shivas, R. G. (2015). Uromycladium falcatarium sp. nov., the cause of gall rust on Paraserianthes falcataria in south-east Asia. Australasian Plant Pathology, 44(1), 25-30. doi:10.1007/s13313-014-0301-z

Gazol, A., Camarero, J. J., Sangüesa-Barreda, G., \& Vicente-Serrano, S. M. (2018). Post-drought resilience after forest die-off: shifts in regeneration, composition, growth and productivity. Frontiers in plant science, 9, 1546. doi:10.3389/fpls.2018.01546

Gazol, A., Camarero, J. J., Vicente-Serrano, S. M., Sánchez-Salguero, R., Gutiérrez, E., de Luis, M., . . . Tíscar, P. A. (2018). Forest resilience to drought varies across biomes. Global change biology, 24(5), 2143-2158. doi:10.1111/gcb.14082

Gnonlonfoun, I., Assogbadjo, A. E., Gnanglè, C. P., \& Kakaï, R. L. G. (2019). New indicators of vulnerability and resilience of agroforestry systems to climate change in West Africa. Agronomy for Sustainable Development, 39(2), 23. doi:10.1007/s13593-019-0566-2

Hamdani, F. A. U., Darusman, D., \& Tiryana, T. T. (2015). Evaluasi praktik tebang butuh di hutan rakyat Kabupaten Ciamis Provinsi Jawa Barat. RISALAH KEBIJAKAN PERTANIAN DAN LINGKUNGAN: Rumusan Kajian Strategis Bidang Pertanian dan Lingkungan, 2(1), 3341.

Hart, S. J., Henkelman, J., McLoughlin, P. D., Nielsen, S. E., Truchon-Savard, A., \& Johnstone, J. F. (2019). Examining forest resilience to changing fire frequency in a fire-prone region of boreal forest. Global change biology, 25(3), 869-884. doi:10.1111/gcb.14550

Holling, C. S., \& Gunderson, L. H. (2002). Resilience and adaptive cycles. In L. H. G. C. S. Holling (Ed.), Panarchy: Understanding Transformations in Human and Natural Systems (pp. 25-62). Washington D.C.: Island Press.

Lumintang, F. M. (2013). Analisis Pendapatan Petani Padi Di Desa Teep Kecamatan Langowan Timur. JURNAL RISET EKONOMI, MANAJEMEN, BISNIS DAN AKUNTANSI, 1(3), 991-998

Messier, C., Bauhus, J., Doyon, F., Maure, F., SousaSilva, R., Nolet, P., . . Puettmann, K. (2019). The functional complex network approach to foster forest resilience to global changes. Forest Ecosystems, 6(1), 1-16. doi:10.1186/s40663-019-0166-2

Rahayu, S. (2010). Modul pelatihan karat tumor pada sengon dan pengelolaannya. Yogyakarta: Gadjah Mada University.

Statistic-Indonesia-of-West-Java. (2015). Statistical Year Book of West Java 2015. Bandung: BPS Jawa Barat.

Statistics-Indonesia-of-West-Java. (2014). Statistical Yearbook of West Java 2014.

Syakirin, A. M. (2014). Tingkat keparahan dan intensitas penyakit karat tumor tegakan sengon (Paraserianthes falcataria (L.) Nielsen) pada hutan rakyat di Bogor. (Bachelor), Bogor Agricultural Institute, Bogor.

US-Census-Bureau (Cartographer). (2015). Most populated countries in the world. 